Check for updates

Cite this: Chem. Sci., 2019, 10, 6476

๑ All publication charges for this article have been paid for by the Royal Society of Chemistry

Received 10th March 2019

Accepted 23rd May 2019

DOI: $10.1039 / \mathrm{c} 9 \mathrm{sc0} 01192 \mathrm{~g}$

rsc.li/chemical-science

\section{A vinyl silylsilylene and its activation of strong homo- and heteroatomic bonds $\uparrow$}

\author{
Matthew M. D. Roy, (D) Michael J. Ferguson, (D) Robert McDonald, (D) Yuqiao Zhou \\ and Eric Rivard (D)*
}

The facile synthesis of a rare two-coordinate acyclic silylene $\left(\mathrm{R}_{2} \mathrm{Si}\right.$ : ) that is stabilized using a bulky vinylic $N$ heterocyclic olefin ligand and the strongly $\sigma$-donating hypersilyl group $\left[\mathrm{Si}\left(\mathrm{SiMe}_{3}\right)_{3}\right]^{-}$is reported. This vinylsubstituted silylene exhibits an excellent combination of prolonged thermal stability along with high reactivity towards small molecules. Despite being stable for months in solution, the reactivity of this new silylene is manifest in its ambient temperature activation of strong $\mathrm{B}-\mathrm{H}, \mathrm{Si}-\mathrm{Cl}, \mathrm{C}-\mathrm{O}, \mathrm{P}-\mathrm{P}$ and $\mathrm{C}-\mathrm{H}$ bonds.

\section{Introduction}

The activation and functionalization of small molecules such as $\mathrm{H}_{2}, \mathrm{CO}, \mathrm{CO}_{2}, \mathrm{P}_{4}{ }^{1}$ and even $\mathrm{N}_{2}{ }^{2}$ by Earth-abundant main group elements usually relies on the isolation of highly reactive element centers. In order to be synthetically viable, a delicate balance of stability and reactivity must be achieved. Amongst p-block compounds, those of Group 14 in the + II oxidation state (tetrelenes) have shown significant promise with regard to bond activation and catalysis. ${ }^{3}$ Silylenes, $\left(\mathrm{R}_{2} \mathrm{Si}\right.$ : still remain rare relative to the other Group 14 tetrelenes, owing in part to the general instability of $\mathrm{Si}^{\mathrm{II}}$ compounds. ${ }^{4}$ While coordinatively saturated examples of silylenes (e.g. $\mathrm{Cp}_{2}{ }_{2} \mathrm{Si} ; \mathrm{Cp}^{*}=\eta^{5}-\mathrm{C}_{5} \mathrm{Me}_{5}$ ) had been reported previously, ${ }^{5}$ West and coworkers prepared the first example of an unsaturated two-coordinate $N$-heterocyclic silylene. ${ }^{6}$ It was only in 2012 that the first examples of isolable two-coordinate acyclic silylenes were simultaneously published (I and II, Scheme 1) ${ }^{7}$ in stark contrast, their heavier $\mathrm{R}_{2} \mathrm{E}$ : congeners $(\mathrm{E}=\mathrm{Ge}, \mathrm{Sn}, \mathrm{Pb} ; \mathrm{R}$ $=$ anionic ligand) were first reported decades prior. ${ }^{8}$ While a few examples of room temperature stable acyclic silylenes are known, ${ }^{7,9}$ all have been stabilized by two heteroatombased ligands. Herein, we utilize a bulky vinylic ligand $\left[{ }^{\mathrm{Me}} \mathrm{IPr}=\mathrm{CH}\right]^{-},\left({ }^{\mathrm{Me}} \mathrm{IPr}=\left[(\mathrm{MeCNDipp})_{2} \mathrm{C}\right] ;\right.$ Dipp $\left.=2,6-{ }^{\mathrm{i}} \mathrm{Pr}_{2} \mathrm{C}_{6} \mathrm{H}_{3}\right)$ to generate the first two-coordinate acyclic silylene stabilized by a carbon-based donor. ${ }^{10}$ Despite the remarkable thermal

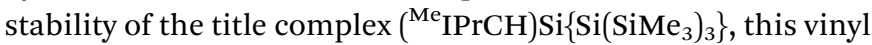
silylsilylene was able to undergo the formal oxidative addition of several strong organic and inorganic bonds, including the regioselective activation/functionalization of white

Department of Chemistry, University of Alberta, 11227 Saskatchewan Drive, Edmonton, Alberta, Canada T6G 2G2.E-mail: erivard@ualberta.ca

$\dagger$ Electronic supplementary information (ESI) available: Full details relating to experimental, crystallographic and computational procedures. CCDC 1901003-1901008. For ESI and crystallographic data in CIF or other electronic format see DOI: 10.1039/c9sc01192g phosphorus $\left(\mathrm{P}_{4}\right)$ and the activation of a primary $\mathrm{C}-\mathrm{H}$ bond at room temperature.

\section{Results and discussion}

This study relied upon the steric bulk and potential 4-electron $(2 \sigma, 2 \pi)$ donating ability of the carbon-based anionic vinylic ligand $\left[{ }^{\mathrm{Me}} \mathrm{IPr}=\mathrm{CH}\right]^{-},{ }^{11}$ to gain access to a two-coordinate silylene. This ligand represents the deprotonated form of its neutral $N$-heterocyclic olefin (NHO) $)^{12}$ parent ${ }^{\mathrm{Me}} \mathrm{IPr}=\mathrm{CH}_{2}$, and this vinylic ligand has been previously used in our group to isolate the first base-free divinylgermylene $\left({ }^{\mathrm{Me}} \mathrm{IPrCH}\right)_{2} \mathrm{Ge} .{ }^{11}$

The first step towards accessing a new organosilylene was to install the $\left[{ }^{\mathrm{Me}} \mathrm{IPr}=\mathrm{CH}\right]^{-}$ligand at silicon. This was achieved by the synthesis of the silane $\left({ }^{\mathrm{Me}} \mathrm{IPrCH}\right) \mathrm{SiBr}_{3}$ (1) from mixing two equivalents of the olefin proligand ${ }^{\mathrm{Me}} \mathrm{IPr}=\mathrm{CH}_{2}$ with $\mathrm{SiBr}_{4}$. After filtration from the flocculant $\left[{ }^{\mathrm{Me}} \mathrm{IPrCH}_{3}\right] \mathrm{Br}$ precipitate, the

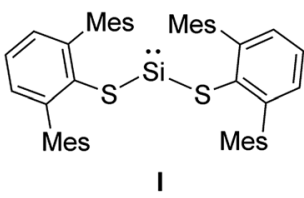

I

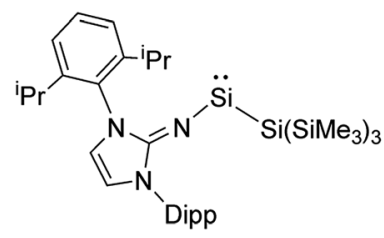

observed at $-78^{\circ} \mathrm{C}$

III

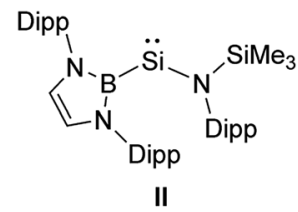

II

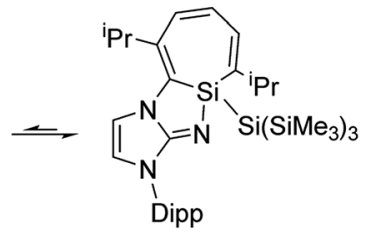

isolated at $R T$
Scheme 1 The first isolable two-coordinate acyclic silylenes (I and II) and the spectroscopically observed iminosilylene III. 
target $\mathrm{Si}^{\mathrm{IV}}$ precursor 1 was isolated as an off-white, crystalline solid in a $53 \%$ yield (Scheme 2). Attempts to the prepare the divinyl silane ( $\left.{ }^{\mathrm{Me}} \mathrm{IPrCH}\right)_{2} \mathrm{SiBr}_{2}$ by combining 1 with an additional two equivalents of ${ }^{\mathrm{Me}} \mathrm{IPr}=\mathrm{CH}_{2}$ or one equivalent of ${ }^{\mathrm{Me}} \mathrm{IPrCH}\left(\mathrm{SiMe}_{3}\right)^{\mathbf{1 1}}$ were unsuccessful. We then focused our synthetic studies on preparing a silylene directly from $\mathbf{1}$.

Following recent reports of bulky silyl-substituted silylenes, ${ }^{5 a, 9 a, c}$ $\left({ }^{\mathrm{Me}} \mathrm{IPrCH} \mathrm{SiBr}_{3}\right.$ (1) was combined with two equivalents of hypersilyl potassium $\left[\mathrm{K}(\mathrm{THF})_{2}\right]\left[\mathrm{Si}\left(\mathrm{SiMe}_{3}\right)_{3}\right]$ in toluene (Scheme 2). This resulted in the immediate formation of deep green slurry. ${ }^{1} \mathrm{H}$ NMR spectroscopic analysis of the filtrate revealed quantitative conversion to a $1: 1$ mixture of a new $\left[{ }^{\mathrm{Me}} \mathrm{IPr}=\mathrm{CH}\right]^{-}$containing product and $\mathrm{BrSi}\left(\mathrm{SiMe}_{3}\right)_{3}$. The vinylic proton signal in the new product exhibited two-bond coupling satellites to $\mathrm{Si}\left({ }^{2} J_{\mathrm{H}-\mathrm{Si}}=13.5 \mathrm{~Hz}\right)$, and its remarkably downfield-positioned chemical shift $\left(\delta 7.40\right.$ in $\left.\mathrm{C}_{6} \mathrm{D}_{6}\right)$ indicates significant transfer of electron density from the $\left[{ }^{\mathrm{Me}} \mathrm{IPr}=\right.$ $\mathrm{CH}]^{-}$ligand to silicon. Additionally, the ${ }^{29} \mathrm{Si}\left\{{ }^{1} \mathrm{H}\right\}$ NMR spectrum displayed a signal at $432.9 \mathrm{ppm}$, which lies in the spectral range of known two-coordinate acyclic silylenes. ${ }^{9}$

To confirm the formation of the two-coordinate silylene $\left({ }^{\mathrm{Me}} \mathrm{IPrCH}\right) \mathrm{Si}\left\{\mathrm{Si}\left(\mathrm{SiMe}_{3}\right)_{3}\right\}$ (2), deep-green crystals suitable for Xray crystallographic analysis were grown from $\mathrm{Me}_{3} \mathrm{SiOSiMe}_{3}$. The molecular structure of 2 (Fig. 1) is in good agreement with the abovementioned NMR results. Specifically, the vinylic C3$\mathrm{C} 4$ bond in 2 [1.406(3) $\AA$ ] is elongated relative to free NHO ${ }^{\mathrm{Me}} \mathrm{IPr}=\mathrm{CH}_{2}[1.3489(18) \AA],{ }^{13}$ providing added evidence for the transfer of $\pi$-electron density to silicon. The C4-Si1-Si2 angle was found to be $101.59(7)^{\circ}$, in line with the presence of a high degree of s-character at the silicon-based lone pair. This angle implies that 2 should have a good balance of stability and reactivity. For example, the colorless dithiolato-supported silylene $\mathrm{Si}\left(\mathrm{SAr}^{\mathrm{Mes}}\right)_{2}$ (I in Scheme 1) has an $\mathrm{R}-\mathrm{Si}-\mathrm{R}$ angle of $90.519(19)^{\circ}$ indicating a relatively low-energy Si-based lone pair of pure s-character. ${ }^{7 a}$ While this molecule has not been reported to cleave strong organic bonds, ${ }^{14}$ acyclic silylenes with obtuse R$\mathrm{Si-R}$ angles (and smaller HOMO-LUMO gaps) have been shown to activate small molecules such as $\mathrm{H}_{2}, \mathrm{CO}_{2}$, and $\mathrm{NH}_{3}{ }^{7 b, 9}$

$\left({ }^{\mathrm{Me}} \mathrm{IPrCH}\right) \mathrm{Si}\left\{\mathrm{Si}\left(\mathrm{SiMe}_{3}\right)_{3}\right\}$ (2) is remarkably stable, with no NMR spectroscopic sign of decomposition noted after storage of a benzene solution at room temperature for two months (under $\mathrm{N}_{2}$ atmosphere). This observation contrasts the situation in Inoue and Rieger's imino silylsilylene (III, Scheme 1), which exists predominately in a 7 -membered $\mathrm{Si}^{\mathrm{IV}}$ ring (silepin) form (via reversible ligand activation) at ambient temperature. ${ }^{9 c}$ Furthermore, our group's attempts to generate the bisiminosilylene $(\mathrm{IPrN})_{2} \mathrm{Si}$ : consistently afforded irreversible ligand activation products. ${ }^{15}$ Additionally, silylenes generated using hypersilyl potassium are often contaminated with the

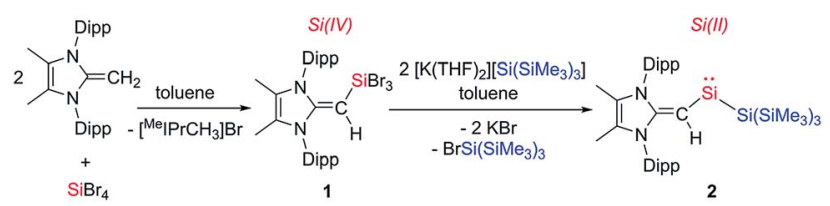

Scheme 2 Formation of the tribromo-vinylsilane 1 and its subsequent reduction to the vinyl silylsilylene 2 .

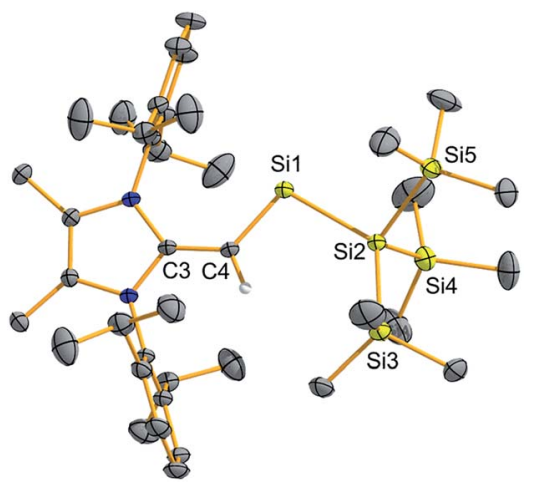

Fig. 1 Molecular structure of $\left({ }^{\mathrm{Me}} \mathrm{IPrCH}\right) \mathrm{Si}\left\{\mathrm{Si}_{\left.\left(\mathrm{SiMe}_{3}\right)_{3}\right\}}\right.$ (2) with thermal ellipsoids plotted at a $30 \%$ probability level. All hydrogen atoms (except the vinylic hydrogen) were omitted for clarity. Selected bond lengths [Å] and angles [']: C3-C4 1.406(3), C4-Si1 1.798(2), Si1-Si2 2.4041; Si1-C4-C3 128.74(15), Si2-Si1-C4 101.59(7).

highly soluble $\mathrm{BrSi}\left(\mathrm{SiMe}_{3}\right)_{3}$ byproduct, ${ }^{\boldsymbol{9} a, c}$ however in our case pure 2 can be obtained in moderate yield (67\%) by washing the crude residue with a minimal amount of cold $\left(-30{ }^{\circ} \mathrm{C}\right)$ $\mathrm{Me}_{3} \mathrm{SiOSiMe}_{3}$.

To gain further insight into the influence of the $\left[{ }^{\mathrm{Me}} \mathrm{IPr}=\right.$ $\mathrm{CH}]^{-}$ligand in 2 , we conducted a series of computational (DFT) studies at the M06-2X/def2-TZVP level. ${ }^{\mathbf{1 6}}$ The computed HOMO of 2 is predominately a silicon-based lone pair whereas the HOMO -1 consists of a $\mathrm{C}-\mathrm{Si} \pi$ bond between the vinylic ligand and the silylene center (Fig. 2). The C-Si Wiberg Bond Index (WBI) was found to be 1.06 and the LUMO shows significant CSi $\pi^{*}$ orbital character. Natural Resonance Theory (NRT) analysis further supports this bonding description, as three of the most relevant resonance structures (Fig. 2, structures B, C and
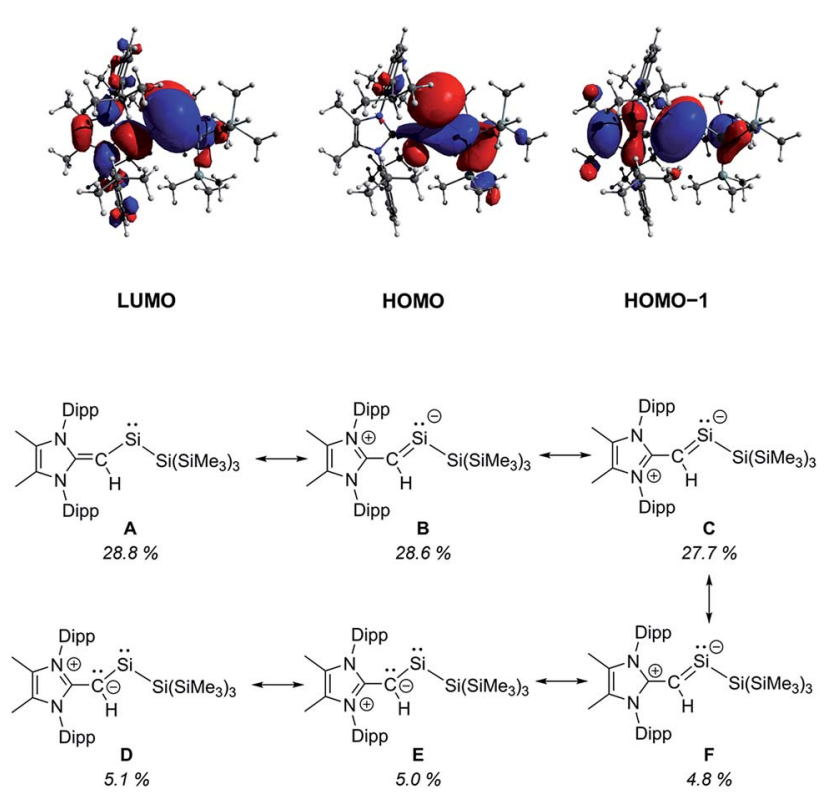

Fig. 2 Selected molecular orbitals of the optimized structure of 2 computed at the M06-2X/def2-TZVP level of theory (top) and relevant Natural Resonance Theory computed resonance structures with their $\%$ weighting (bottom). 
F) contain a C-Si $\pi$ bond with a combined $61.1 \%$ weighting of these structures. Together, these analyses demonstrate the stabilizing $\pi$-donation ability of the $\left[{ }^{\mathrm{Me}} \mathrm{IPr}=\mathrm{CH}\right]^{-}$ligand. Additionally, the computed natural charges show a highly polarized $\mathrm{Si}^{\mathrm{II}}-\mathrm{SiR}_{3}$ bond $\left(\mathrm{Si}^{\mathrm{II}}\right.$ : $\left.+0.54 ; \mathrm{SiR}_{3}:-0.51\right)$ which may enable interesting reactivity to transpire. As a result, we explored the interaction of $\mathbf{2}$ with small molecules in detail.

We began a reactivity study of 2 by combining this silylene with the carbon-based electrophile MeOTf $\left(\mathrm{OTf}=\mathrm{CF}_{3} \mathrm{SO}_{3}\right)$. As anticipated, the deep green color of 2 dissipated upon addition of MeOTf and NMR analysis revealed the formation of a single new product. X-ray crystallography identified this species as the new triflato-silane $\left({ }^{\mathrm{Me}} \mathrm{IPrCH}\right) \mathrm{Si}(\mathrm{Me}) \mathrm{OTf}\left\{\mathrm{Si}\left(\mathrm{SiMe}_{3}\right)_{3}\right\}$ (3) (Scheme 3 , Fig. 3). Compound 3 crystallizes in a distorted tetrahedral geometry, with a covalently bound -OTf unit in the solid state $[\mathrm{Si} 1-\mathrm{O} 1=1.8258(10) \AA]$ and in solution $\left({ }^{19} \mathrm{~F}\left\{{ }^{1} \mathrm{H}\right\}\right.$ NMR: $\delta-75.8$ ppm).

Silylene 2 was then combined with the widely used hydroborylation reagent pinacolborane (HBPin), which led to oxidative addition of an $\mathrm{H}-\mathrm{B}$ bond at silicon to yield $\left({ }^{\mathrm{Me}} \mathrm{IPrCH}\right) \mathrm{Si}(\mathrm{H}) \mathrm{BPin}$ $\left\{\mathrm{Si}\left(\mathrm{SiMe}_{3}\right)_{3}\right\} \quad$ (4) (Scheme 3). When 2 was reacted with trichlorosilane $\left(\mathrm{HSiCl}_{3}\right)$, a new compound was soon observed with a singlet $\mathrm{Si}-\mathrm{H}$ resonance in the ${ }^{1} \mathrm{H}$ NMR spectrum $(\delta 3.61 \mathrm{ppm}$, $\left.{ }^{1} J_{\mathrm{H}-\mathrm{Si}}=180.0 \mathrm{~Hz}\right)$. The lack of ${ }^{3} J_{\mathrm{HH}}$ coupling to the neighbouring vinylic hydrogen implied that oxidative addition of an $\mathrm{Si}-\mathrm{Cl}$ bond had transpired in place of $\mathrm{Si}-\mathrm{H}$ bond activation. ${ }^{17}$ Crystallographic analysis confirmed the formation of $\left({ }^{\mathrm{Me}} \mathrm{IPrCH}\right)$ $\mathrm{SiCl}\left(\mathrm{HSiCl}_{2}\right)\left\{\mathrm{Si}\left(\mathrm{SiMe}_{3}\right)_{3}\right\}$ (5) (Fig. 4). Of note, the addition of $\mathrm{HSiCl}_{3}$ across a silylene (such as $\mathrm{Cl}_{2} \mathrm{Si}$ :) is a key step proposed in the chemical vapour deposition (CVD) of epitaxial silicon from trichlorosilane. ${ }^{18}$ The sterically congested nature of 5 is evident by its ${ }^{1} \mathrm{H}$ and ${ }^{13} \mathrm{C}\left\{{ }^{1} \mathrm{H}\right\}$ NMR spectra which are very broad at room temperature but are resolved at $+75{ }^{\circ} \mathrm{C}$. The molecular structure of 5 (Fig. 4) shows an expected distorted tetrahedral geometry at Si1 [Si2-Si1-Si3: 109.81(9) ${ }^{\circ}$. Interestingly, the located silane hydrogen atom was found to exhibit an $\mathrm{SiH}-\pi$ interaction in the

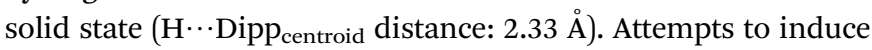
dehydrochlorination of $\mathbf{5}$ (to form a dichlorodisilene, $\mathrm{RR}^{\prime} \mathrm{Si}=$ $\mathrm{SiCl}_{2}$ ) using the strong Brønsted bases DABCO (DABCO $=1,4$ diazabicyclo[2.2.2]octane) or the $N$-heterocyclic carbene (MeCNMe) ${ }_{2} \mathrm{C}$ : were unsuccessful. ${ }^{19}$ In both cases, no reaction was observed, perhaps owing to steric protection of the $\mathrm{Si}-\mathrm{H}$ bond.

Encouraged by the activation of polarized heteroatomic bonds using 2 , we decided to investigate whether silylene 2 would react with the non-polar bonds of white phosphorus $\left(\mathrm{P}_{4}\right)$.

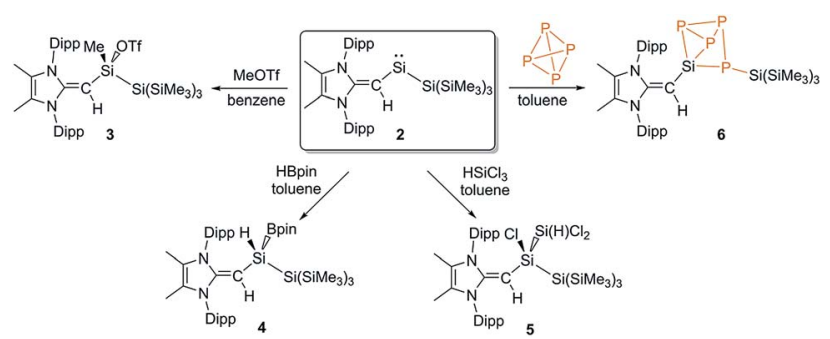

Scheme 3 Oxidative addition of the substrates MeOTf (3), HBpin (4), $\mathrm{HSiCl}_{3}(5)$ and $\mathrm{P}_{4}(6)$ to the reactive silylene 2.

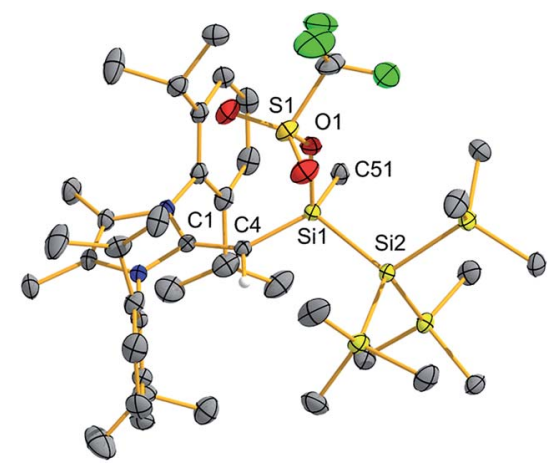

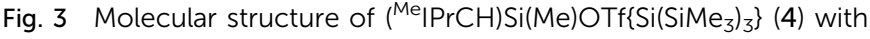
thermal ellipsoids plotted at a $30 \%$ probability level. All hydrogen atoms (except the vinylic hydrogen) were omitted for clarity. Selected bond lengths $[\AA \AA]$ and angles [ $\left.{ }^{\circ}\right]$ : C1-C4 1.3964(17), C4-Si1 1.7929(13), Si1-O1 1.8258(10); C4-Si1-O1 111.37(5), C4-Si1-C51 121.69(6), C4Si1-Si2 111.04(4).

While acyclic silylenes have not yet been shown to react with $\mathrm{P}_{4}$, several examples of cyclic silylenes reacting with $\mathrm{P}_{4}$ are known. These reactions are limited to the oxidative addition of a single $\mathrm{P}-\mathrm{P}$ bond across a silicon center, ${ }^{20}$ and the controlled activation/ functionalization of $\mathrm{P}_{4}$ by main group elements remains a difficult transformation. ${ }^{21}$ Upon mixing 2 and $\mathrm{P}_{4}$ for 20 minutes at room temperature, a pale orange solution was formed. ${ }^{31} \mathrm{P}\left\{{ }^{1} \mathrm{H}\right\}$ NMR analysis suggested that simple oxidative addition of a P-P had not occurred, as three distinct signals were observed $(\delta 120.0,-181.0,-316.7 \mathrm{ppm}) .{ }^{16} \mathrm{X}$-ray crystallographic analysis revealed that a 1,2-migration of the hypersilyl group of 2 transpired in addition to $\mathrm{P}_{4}$ reduction (Scheme 3, Fig. 5) to yield $\left({ }^{\mathrm{Me}} \mathrm{IPrCH}\right) \mathrm{Si}\left(\mathrm{P}_{4}\right)\left\{\mathrm{Si}\left(\mathrm{SiMe}_{3}\right)_{3}\right\}$ (6). This transformation is likely facilitated by the steric bulk of 2 and the polarized nature of the $\mathrm{Si}^{\mathrm{II}}-\mathrm{Si}\left(\mathrm{SiMe}_{3}\right)_{3}$ bond (vide supra). While the mechanism of this reaction likely involves first the oxidative addition of a $\mathrm{P}-\mathrm{P}$ bond of $\mathrm{P}_{4}$ to silylene 2 , followed by a 1,2-silyl migration, we did not observe any experimental evidence for

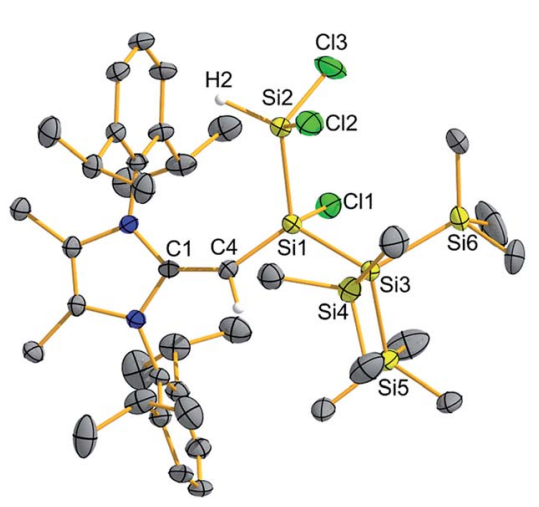

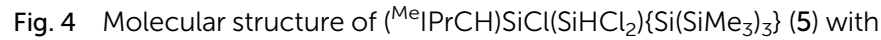
thermal ellipsoids plotted at a $30 \%$ probability level. All hydrogen atoms (except the vinylic hydrogen and silane hydrogen) were omitted for clarity. Selected bond lengths [Å] and angles [ $\left.{ }^{\circ}\right]$ : C1-C4 1.394(7), C4-Si1 1.789(5), Si1-Si2 2.364(2), Si1-Cl1 2.170(2), Si2-H2 1.50(7), Si2Cl2 2.076(3), 2.074(3), Si1-Si3 2.358(2); Si2-Si1-Si3 109.81(9), Si2Si1-Cl1 100.27(9), Si2-Si1-C4 118.15(19). 


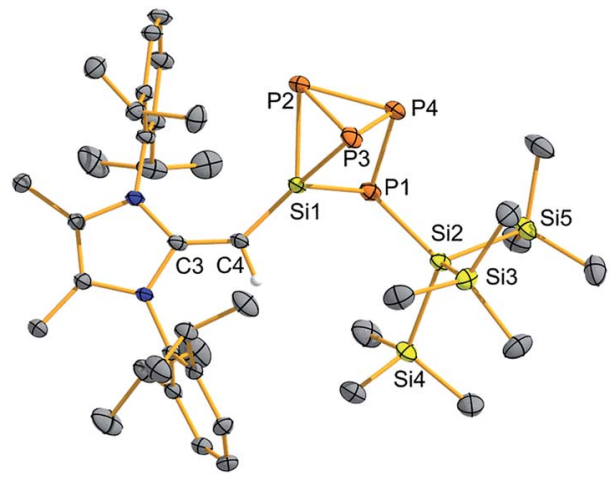

Fig. 5 Molecular structure of $\left({ }^{\mathrm{Me}} \mathrm{IPrCH}\right) \mathrm{Si}\left(\mathrm{P}_{4}\right)\left\{\mathrm{Si}\left(\mathrm{SiMe}_{3}\right)_{3}\right\}$ (6) with thermal ellipsoids plotted at a $30 \%$ probability level. All hydrogen atoms (except the vinylic hydrogen) were omitted for clarity. Selected bond lengths $[\AA \AA]$ and angles [ $\left.{ }^{\circ}\right]$ : C3-C4 1.380(4), C4-Si1 1.792(3), Si1P1 2.2407(11), Si1-P2 2.2364(10), Si1-P3 2.2639(10), P2-P3 2.2555(12), P2-P4 2.2262(12), P3-P4 2.2057(13), P4-P1 2.2615(10), P1-Si2 2.2775(11); C4-Si1-P1 123.42(11), P4-P1-Si1 75.18(4), P4-P1-Si2 104.06(4), P3-P2-P4 58.96(4).

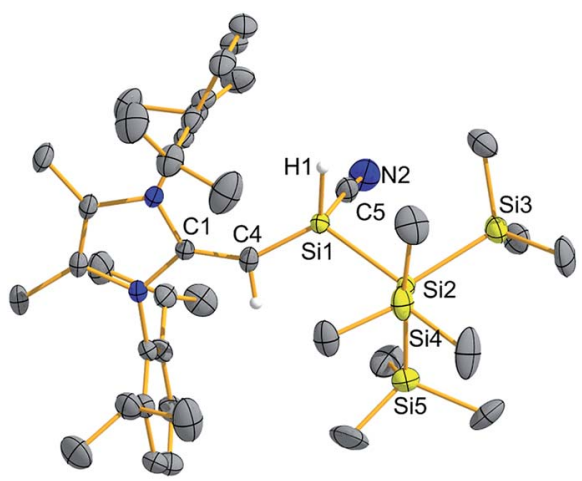

Fig. 6 Molecular structure of $\left(\mathrm{Me}_{\mathrm{IPrCH}}\right) \mathrm{SiH}(\mathrm{CN})\left\{\mathrm{Si}\left(\mathrm{SiMe}_{3}\right)_{3}\right\}$ (7) with thermal ellipsoids plotted at a $30 \%$ probability level. All hydrogen atoms (except the vinylic and silicon-bound hydrogens) were omitted for clarity. Selected bond lengths $[\AA]]$ and angles $\left[{ }^{\circ}\right]$ : C4-Si1 1.709(3), Si1-H1 1.46(5), Si1-Si2 2.3396(15), Si1-C5 1.918(5), C5-N2 1.110(7); C4-S1-Si2 116.64(10), C4-Si1-C5 111.9(2), Si1-C5-N2 175.0(6).

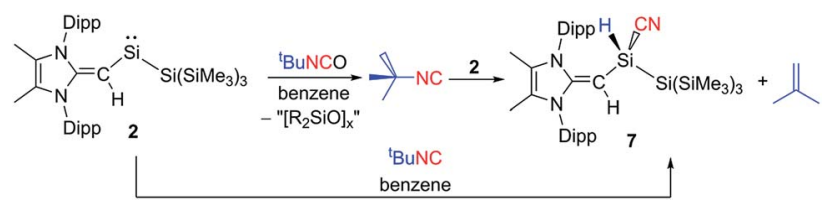

Scheme 4 Formation of the silyl-cyanide 7 via reaction of 2 with ${ }^{t} \mathrm{BuCN}$.

this postulated oxidative addition intermediate. ${ }^{22}$ The observed activation/functionalization of $\mathrm{P}_{4}$ by 2 represents the cleavage of two P-P bonds and the regioselective formation of four new Si-P bonds. Remarkably, a search of the Cambridge Structural Database (CSD) revealed that compound 6 represents an entirely new bonding motif for the $\mathrm{P}_{4}{ }^{2-}$ ligand. ${ }^{23}$ Notably, silylated phosphines and phosphides are valuable precursors to element phosphide nanomaterials ${ }^{24}$ and organophosphines ${ }^{25}$ and thus their preparation from elemental phosphorus continues to be of great importance.

Following the remarkable report by Rieger, Inoue and coworkers of an isolable three-coordinate silanone (formed by oxidation of III in Scheme 1 with $\left.\mathrm{N}_{2} \mathrm{O}\right)^{26}$ we wondered whether 2 would react in a similar manner. Surprisingly, exposure of a solution of 2 to an $\mathrm{N}_{2} \mathrm{O}$ atmosphere at $-78{ }^{\circ} \mathrm{C}$ or room temperature afforded no reaction. Subsequently, 2 was combined with one equivalent of the potential oxygen-atom source tert-butyl isocyanate ( $\left.{ }^{t} \mathrm{BuNCO}\right)$ which yielded a mixture of products by ${ }^{1} \mathrm{H}$ NMR spectroscopy, including several $\left[{ }^{\mathrm{Me}} \mathrm{IPr}=\right.$ $\mathrm{CH}]^{-}$containing species, unreacted ${ }^{t}$ BuNCO and isobutylene. Extraction of the mixture with hexanes and crystallization afforded crystals of the silyl-cyanide $\left({ }^{\mathrm{Me}} \mathrm{IPrCH}\right) \mathrm{SiH}(\mathrm{CN})$ $\left\{\mathrm{Si}\left(\mathrm{SiMe}_{3}\right)_{3}\right\}(7)$ in low (31\%) yield (Fig. 6). Compound 7 is likely formed from the isocyanide ( $\left.{ }^{t} \mathrm{BuNC}\right)$ by-product generated after the initial oxidation of 2 with ${ }^{t}$ BuNCO (Scheme 4). Thus far, we have been unable to isolate and identify the other products in the mixture, including the possible silanone by-product

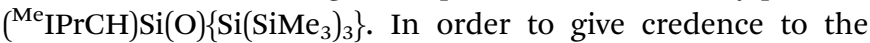
proposed mechanism, 2 was combined with one equivalent of ${ }^{t} \mathrm{BuNC}$, which led to the quantitative formation of a $1: 1$ mixture of 7 and isobutylene (as determined by ${ }^{1} \mathrm{H}$ NMR spectroscopy). This transformation represents a quantitative room temperature activation of a primary $\mathrm{C}-\mathrm{H}$ bond by a silylene $\left(\mathrm{R}_{2} \mathrm{Si}\right.$ :). Related transformations have been demonstrated previously with an acyclic germylene ${ }^{27}$ and a disilene, ${ }^{28}$ albeit at elevated temperatures.

\section{Conclusions}

In this work, the synthesis of a thermally stable, two-coordinate acyclic silylene $\left({ }^{\mathrm{Me}} \mathrm{IPrCH}\right) \mathrm{Si}\left\{\mathrm{Si}\left(\mathrm{SiMe}_{3}\right)_{3}\right\}$ was achieved, and is the first example of such a species supported by a carbon-based ligand. The stabilizing influence of $\left[{ }^{\mathrm{Me}} \mathrm{IPr}=\mathrm{CH}\right]^{-}$was evaluated experimentally and computationally. The high reactivity of this new silylene was demonstrated by its room temperature activations of strong homo- and heteroatomic bonds. Future work will target the synthesis of more nucleophilic sources of $\left[{ }^{\mathrm{Me}} \mathrm{IPr}=\mathrm{CH}\right]^{-}$which may allow for the formation of a stable divinylsilylene and related reactive species for main group element-based catalysis.

\section{Conflicts of interest}

There are no conflicts to declare.

\section{Acknowledgements}

E. R. thanks the NSERC of Canada for Discovery and CREATE grants, the Canada Foundation for Innovation, and the University of Alberta, Faculty of Science (Research Award) for funding. The computational studies in this work were made possible by the facilities of Compute/Calcul Canada (www.computecanada.ca). We thank Dr Paul Lummis for preliminary experimental investigations and Dr Emanuel Hupf 
for helpful discussions. Mr Mark Miskolzie is gratefully acknowledged for his assistance acquiring ${ }^{29} \mathrm{Si}$ and variable temperature NMR spectra and Prof. Alex Brown for his helpful discussions relating to the computational work presented. We also thank Mr Samuel Baird for creating the TOC graphic. E. R. thanks the Alexander von Humboldt Foundation for fellowship.

\section{Notes and references}

1 For recent reviews and articles, see: (a) T. Chu and G. I. Nikonov, Chem. Rev., 2018, 118, 3608; (b) P. P. Power, Nature, 2010, 463, 171; (c) C. Weetman and S. Inoue, ChemCatChem, 2018, 10, 4213; (d) R. L. Melen, Science, 2019, 363, 479; (e) A. S. S. Wilson, M. S. Hill, M. F. Mahon, C. Dinoi and L. Maron, Science, 2017, 358, 1168; $(f)$ F.-G. Fontaine and E. Rochette, Acc. Chem. Res., 2018, 51, 454; $(g)$ J. Hicks, P. Vasko, J. M. Goicoechea and S. Aldridge, Nature, 2018, 557, 92; (h) Y. Wang, A. Kostenko, T. J. Hadlington, M.-P. Luecke, S. Yao and M. Driess, J. Am. Chem. Soc., 2019, 141, 626.

2 M.-A. Légaré, G. Bélanger-Chabot, R. D. Dewhurst, E. Welz, I. Krummenacher, B. Engels and H. Braunschweig, Science, 2018, 359, 896.

3 (a) K. A. Miller, T. W. Watson, J. E. Bender, M. M. Banaszak Holl and J. W. Kampf, J. Am. Chem. Soc., 2001, 123, 982; (b) Y. Peng, B. D. Ellis, X. Wang and P. P. Power, J. Am. Chem. Soc., 2008, 130, 12268; (c) Y. Peng, J.-D. Guo, B. D. Ellis, Z. Zhu, J. C. Fettinger, S. Nagase and P. P. Power, J. Am. Chem. Soc., 2009, 131, 16272; (d) S. K. Mandal and H. W. Roesky, Acc. Chem. Res., 2011, 45, 298; (e) K. Inomata, T. Watanabe, Y. Miyazaki and H. Tobita, J. Am. Chem. Soc., 2015, 137, 11935; (f) A. V. Protchenko, J. I. Bates, L. M. A. Saleh, M. P. Blake, A. D. Schwarz, E. L. Kolychev, A. L. Thompson, C. Jones, P. Mountford and S. Aldridge, J. Am. Chem. Soc., 2016, 138, 4555; $(g)$ M. M. D. Roy, S. Fujimori, M. J. Ferguson, R. McDonald, N. Tokitoh and E. Rivard, Chem.-Eur. J., 2018, 24, 14392; (h) T. J. Hadlington, M. Driess and C. Jones, Chem. Soc. Rev., 2018, 47, 4176.

4 Y. Mizuhata, T. Sasamori and N. Tokitoh, Chem. Rev., 2009, 109, 3479; M. Asay, C. Jones and M. Driess, Chem. Rev., 2011, 111, 354; E. Rivard, Chem. Soc. Rev., 2016, 45, 989.

5 (a) P. Jutzi, U. Holtmann, D. Kanne, C. Krüger, R. Blom, R. Gleiter and I. Hyla-Kryspin, Chem. Ber., 1989, 122, 1629; (b) H. H. Karsch, U. Keller, S. Gamper and G. Müller, Angew. Chem., Int. Ed. Engl., 1990, 29, 295; (c) M. Kumar Bisai, V. S. V. S. V. S. N. Swamy, T. Das, K. Vanka, R. G. Gonnade and S. S. Sen, Inorg. Chem., 2019, DOI: 10.1021/acs.inorgchem.9b00418.

6 M. Denk, R. Lennon, R. Hayashi, R. West, A. V. Belyakov, H. P. Verne, A. Haaland, M. Wagner and N. Metzler, J. Am. Chem. Soc., 1994, 116, 2691.

7 (a) B. D. Rekken, T. M. Brown, J. C. Fettinger, H. M. Tuononen and P. P. Power, J. Am. Chem. Soc., 2012, 134, 6504; (b) A. V. Protchenko, K. H. Birjkumar, D. Dange, A. D. Schwarz, D. Vidovic, C. Jones, N. Kaltsoyannis,
P. Mountford and S. Aldridge, J. Am. Chem. Soc., 2012, 134, 6500.

8 M. J. S. Gynane, D. H. Harris, M. F. Lappert, P. P. Power, P. Rivière and M. Rivière-Baudet, J. Chem. Soc., Dalton Trans., 1977, 2004.

9 (a) A. V. Protchenko, A. D. Schwarz, M. P. Blake, C. Jones, N. Kaltsoyannis, P. Mountford and S. Aldridge, Angew. Chem., Int. Ed., 2013, 52, 568; (b) T. J. Hadlington, J. A. B. Abdalla, R. Tirfoin, S. Aldridge and C. Jones, Chem. Commun., 2016, 52, 1717; (c) D. Wendel, A. Porzelt, F. A. D. Herz, D. Sakar, C. Jandl, S. Inoue and B. Rieger, J. Am. Chem. Soc., 2017, 139, 8134; (d) Y. K. Loh, L. Ying, M. Á. Fuentes, D. C. H. Do and S. Aldridge, Angew. Chem., Int. Ed., 2019, 58, 4847.

10 A cyclic dialkylsilylene has been previously reported: M. Kira, S. Ishida, T. Iwamoto and C. Kabuto, J. Am. Chem. Soc., 1999, 121, 9722.

11 (a) C. Hering-Junghans, P. Andreiuk, M. J. Ferguson, R. McDonald and E. Rivard, Angew. Chem., Int. Ed., 2017, 56, 6272; $(b)$ For an example of a base-stabilized divinylgermylene, see: M. Walewska, J. Baumgartner and C. Marschner, Chem. Commun., 2015, 51, 276.

12 For reviews on NHO ligands, see: (a) R. S. Ghadwal, Dalton Trans., 2016, 45, 16081; (b) R. D. Crocker and T. V. Nguyen, Chem.-Eur. J., 2016, 22, 2208; (c) M. M. D. Roy and E. Rivard, Acc. Chem. Res., 2017, 50, 2017.

13 K. Powers, C. Hering-Junghans, R. McDonald, M. J. Ferguson and E. Rivard, Polyhedron, 2016, 108, 8.

14 Dithiolatosilylenes have been reported to reversibly bind ethylene: F. Lips, J. C. Fettinger, A. Mansikkamäki, H. M. Tuononen and P. P. Power, J. Am. Chem. Soc., 2014, 136, 634.

15 M. W. Lui, C. Merten, M. J. Ferguson, R. McDonald, Y. Xu and E. Rivard, Inorg. Chem., 2015, 54, 2040.

16 For full crystallographic, computational, and experimental details see the ESI. $\uparrow$ CCDC 1901003 to 1901008 contain the supplementary crystallographic data for this manuscript. $\dagger$

17 A similar reaction has been previously reported for a cyclic silylene, however a mixture of two products was observed: Y. Xiong, S. Yao and M. Driess, Organometallics, 2009, 28, 1927.

18 M. T. Swihart and R. W. Carr, J. Phys. Chem. A, 1998, 102, 1542.

19 Hydrodechlorination of chlorosilanes using strong neutral bases is known. For example: R. S. Ghadwal, H. W. Roesky, S. Merkel, J. Henn and D. Stalke, Angew. Chem., Int. Ed., 2009, 48, 5683.

20 (a) M. Driess, A. D. Fanta, D. R. Powell and R. West, Angew. Chem., Int. Ed. Engl., 1989, 28, 1038; (b) Y. Xiong, S. Yao, M. Brym and M. Driess, Angew. Chem., Int. Ed., 2007, 46, 4511; (c) S. S. Sen, S. Khan, H. W. Roesky, D. Kratzert, K. Meindl, J. Henn, D. Stalke, J.-P. Demers and A. Lange, Angew. Chem., Int. Ed., 2011, 50, 2322.

21 For selected reviews of $\mathrm{P}_{4}$ activation by main group elements, see: (a) M. Scheer, G. Balázs and A. Seitz, Chem. Rev., 2010, 110, 4236; (b) S. Khan, S. S. Sen and H. W. Roesky, Chem. Commun., 2012, 48, 2169; (c) J. E. Borger, A. W. Ehlers, 
J. C. Slootweg and K. Lammertsma, Chem.-Eur. J., 2017, 23, 11738.

22 In an attempt to observe this potential intermediate, the reaction of $2+\mathrm{P}_{4}$ was monitored by ${ }^{31} \mathrm{P}\left\{{ }^{1} \mathrm{H}\right\} \quad \mathrm{NMR}$ spectroscopy in toluene-d8. At $-80{ }^{\circ} \mathrm{C}$, we observed only 6 + unreacted $\mathrm{P}_{4}$. At $-60{ }^{\circ} \mathrm{C}$ and above, several new signals were observed, however none of the signals clearly correspond to a $\mathrm{P}_{4}$-containing intermediate. In contrast, when the reaction of $2+\mathrm{P}_{4}$ was monitored by ${ }^{31} \mathrm{P}\left\{{ }^{1} \mathrm{H}\right\}$ NMR at room temperature, clean conversion to 6 was observed. This divergent reactivity may be due to significantly different solubilities of $\mathrm{P}_{4}$ and 2 at low temperature, thus altering the effective stoichiometry in solution.
23 The activation of $\mathrm{P}_{4}$ by $\mathrm{H}_{2} \mathrm{Si}$ : has been studied computationally. Interestingly, none of the located minima on the potential energy surface correspond to compound 6: R. Damrauer and S. E. Pusede, Organometallics, 2009, 28, 1289.

24 For example: D. C. Gary and B. M. Cossairt, Chem. Mater., 2013, 25, 2463.

25 M. B. Geeson and C. C. Cummins, Science, 2018, 359, 1383. 26 D. Wendel, D. Reiter, A. Porzelt, P. J. Altmann, S. Inoue and B. Rieger, J. Am. Chem. Soc., 2017, 139, 17193.

27 Z. D. Brown, P. Vasko, J. C. Fettinger, H. M. Tuononen and P. P. Power, J. Am. Chem. Soc., 2012, 134, 4045.

28 N. Takeda, T. Kajiwara, H. Suzuki, R. Okazaki and N. Tokitoh, Chem.-Eur. J., 2003, 9, 3530. 